\title{
UGT1A1 Gene
}

National Cancer Institute

\section{Source}

National Cancer Institute. UGT1A1 Gene. NCI Thesaurus. Code C20128.

This gene is involved in controlling serum levels of bilirubin and in glucuronidation. 